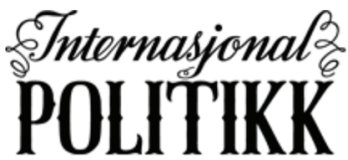 \\ SKANDINAVISK TIDSSKRIFT \\ FOR INTERNASIONALE STUDIER
}

Årgang 78, Nummer 3, side 284-310, 2020, ISSN 1891-1757, www.tidsskriftet-ip.no, Publisert september 2020

\section{Arktisk råd i spennet mellom forskning, forvaltning og politikk}

\author{
Svein Vigeland Rottem* \\ Fridtjof Nansens Institutt, Norge \\ Ida Folkestad Soltvedt \\ Tidligere, Fridtjof Nansens Institutt, Norge \\ Christian Prip \\ Fridtjof Nansens Institutt, Norge
}

\section{Sammendrag}

Det som ofte har manglet i forskningslitteraturen om miljø- og klimautfordringer i Arktis, er undersøkelser av hva som betinger innflytelsen av vitenskapelig kunnskap i reguleringer av relevans for Arktis. I denne artikkelen er målet å analysere forholdet mellom arktisk kunnskapsproduksjon (inkludert policyanbefalinger) og norsk forvaltning (herunder Miljødirektoratet og Klima- og miljødepartementet). I artikkelen ser vi nærmere på tre av arbeidsgruppene i Arktisk råd: 1) Arctic Monitoring and Assessment Programme (AMAP), 2) Conservation of Arctic Flora and Fauna (CAFF) og 3) Protection of the Arctic Marine Environment (PAME). Fokus er på kunnskapsstatus, grad av økonomisk og politisk kontrovers innenfor de gitte feltene, betydningen av offentlig og politisk oppmerksomhet og forvaltningsdesign.

Nøkkelord: Arktisk råd · AMAP • CAFF • PAME • kunnskap • nasjonal miljøforvaltning

\footnotetext{
^Kontaktinformasjon: svr@fni.no

(C2020 Svein Vigeland Rottem, Ida Folkestad Soltvedt og Christian Prip. This is an Open Access article distributed under the terms of the Creative Commons Attribution 4.0 International License (http://creativecommons.org/licenses/by/4.0/), allowing third parties to copy and redistribute the material in any medium or format and to remix, transform, and build upon the material for any purpose, even commercially, provided the original work is properly cited and states its license. Citation: Svein Vigeland Rottem, Ida Folkestad Soltvedt og Christian Prip (2020). Arktisk råd $i$ spennet mellom forskning, forvaltning og politikk. Internasjonal Politikk, 78(3): 284-310. http://dx.doi.org/10.23865/intpol.v78.1504
} 


\section{Introduksjon ${ }^{1}$}

Klima- og miljøutfordringer i Arktis har vært høyt på den internasjonale forskningsdagsordenen de seneste år, og kunnskap om utviklingen i nord har spilt inn i internasjonal og nasjonal politikkutforming. Dette understøttes også av enkelte juridiske og samfunnsvitenskapelige analyser, som tyder på at «arktisk kunnskap» har gjort en forskjell (se Duyck, 2012; Kankaanpää \& Young, 2012; Soltvedt \& Rottem, 2016; Prip, 2016; Rottem, 2017; Soltvedt, 2017; Platjouw, Steindal \& Borch, 2018). I denne artikkelen ser vi nærmere på den viktigste kunnskapsaktøren i Arktis - Arktisk råd - som gjennom en årrekke har satt dagsordenen for kunnskapsutviklingen i nord. Nærmere bestemt er søkelyset på kunnskapssammenstilling og -formidling i tre av rådets arbeidsgrupper: Arctic Monitoring and Assessment Programme (AMAP), Conservation of Arctic Flora and Fauna (CAFF) og Protection of the Arctic Marine Environment (PAME). Disse er valgt da det er her den viktigste kunnskapsinnhentingen i Arktisk råd finner sted. Spørsmålet vi stiller oss er: Hvorfor og hvordan anvendes vitenskapelig kunnskap fra Arktisk råds arbeidsgrupper?

Formålet med artikkelen er å legge til rette for en informert diskusjon om hvordan arktisk kunnskap etableres og brukes i spennet mellom forskning, forvaltning og politikk. Vi ønsker også å legge grunnlaget for videre forskning om Arktisk råds rolle i internasjonale reguleringer og nasjonal forvaltning. Dette er og har vært mangelvare. Søkelyset har i stor grad vært på utvikling av naturvitenskapelig kunnskap, og mindre på hvordan og hvorfor noen typer kunnskap blir ansett som relevant og i siste instans blir anvendt. Et hovedmål i artikkelen er dermed å argumentere for nødvendigheten av en utvidet forskningsdagsorden i nord. Vi vil vise den bredden som finnes, og forhåpentligvis gi innspill til flere, mer dyptgående casestudier innenfor temaer som klima, miljøgifter, biodiversitet og forurensning. Det brede empiriske tilfanget tilsier at vi ikke kan dykke dypt inn i hver arbeidsgruppe og rekken av forskningsfelt som dekkes av dem. Analysen baseres derfor på et utvalg rapporter og temaer fra AMAP, CAFF og PAME.Vi bruker også Norge som en illustrerende case.

Artikkelen er i stor grad empirisk drevet, men for å belyse problemstillingen er det nødvendig å anvende et sett av analytiske verktøy. Dette både for å strukturere diskusjonene om forholdet mellom vitenskap og politikk og for å sammenligne funnene innad i den enkelte arbeidsgruppen og mellom dem. Slik viser vi blant annet hvordan arktisk kunnskap brukes på en rekke ulike måter. I påfølgende avsnitt presenterer vi disse verktøyene, våre data og hvordan artikkelen er disponert.

Kunnskap og politikk

Det finnes en omfattende vitenskapelig litteratur om forholdet mellom kunnskap og politikk (Clark et al., 1998; Andresen, Skodvin, Underdal \& Wettestad, 2000;

\footnotetext{
${ }^{1}$ Forfatterne vil takke alle som har stilt til intervju, redaksjonen ved Internasjonal Politikk og to anonyme fagfeller for gode innspill i arbeidet med denne artikkelen.
} 
Jasanoff, 2004; Lidskog \& Sundqvist, 2015). For å svare på problemstillingen har vi valgt ut fire faktorer basert på denne litteraturen, som kan si noe om hvorfor og hvordan kunnskapen fra Arktisk råds arbeidsgrupper blir brukt. Et vanlig utgangspunkt er at dersom kunnskap skal «vinne fram» på internasjonale beslutningsarenaer og i nasjonal forvaltning, må det være bred vitenskapelig enighet om problemets karakter og til en viss grad om hvordan det kan løses. I denne sammenheng er ofte graden av presisjon i kunnskapen (og policyanbefalinger som springer ut av denne kunnskapen) sentralt. Et avgrenset felt hvor forholdet mellom målet og middelet er tydelig, vil lettere fanges opp i internasjonale forhandlinger og i nasjonal forvaltning og dermed bli gjenstand for reguleringer. Et tilbakevendende eksempel hvor dette skjedde, er ozonforhandlingene som munnet ut i Montrealprotokollen (Andresen, Rosendal \& Skjærseth, 2017). Det finnes likevel også eksempler hvor det trengs mer enn bred vitenskapelig enighet. Klimaendringene er kroneksemplet her (Andresen et al., 2017). For å kunne forklare suksess eller ikke må dermed andre variabler trekkes inn. I litteraturen hevdes det gjerne at graden av økonomisk og politisk kontrovers rundt et gitt tema er avgjørende for å forklare hvorvidt kunnskap blir brukt. Dette er ikke overraskende, men likevel viktig å bringe inn i enhver analyse av forholdet mellom kunnskap og politikk (Andresen et al., 2000). En tredje utbredt forklaring er koblet til hvor høyt en gitt utfordring er på den offentlige og politiske agendaen. For eksempel er det nærliggende å anta at høy offentlig og politisk oppmerksomhet øker sannsynligheten for at kunnskap blir brukt.

Tilnærmingen ovenfor er nyttig fordi den begrenser analysens omfang og tillater oss å undersøke relevante variabler. Samtidig er den blitt kritisert for å gi en forenklet enveisforståelse av forholdet mellom kunnskap og politikk. Beck (2010) beskriver den som en «lineær modell», hvor det er et klart skille mellom vitenskap og forvaltning og politikk. Det ligger en forventning om at kunnskap oppstår forut for og er klart adskilt fra det politiske nivået. De tre faktorene presentert ovenfor, kan dermed være «hindringer» kunnskapen møter på veien mot å bli politikk.

Den fjerde faktoren vi tar i bruk, tar hensyn til dette. Begrepet "co-production» (Jasanoff, 2004; Lidskog \& Sundqvist, 2015), på norsk "samproduksjon", vektlegger at man ikke kan trekke et så bastant analytisk skille mellom kunnskap og politikk. De er gjensidig konstituerende: Politikk påvirker utviklingen av kunnskap samtidig som kunnskapen støtter og rettferdiggiør politikk. Kunnskap er dermed et beslutningsgrunnlag for konkrete forvaltningsmessige eller politiske vedtak, men er også med på å legitimere større diskurser og egeninteresser. Bruker for eksempel miljøforvaltningen i Norge kunnskap sammenstilt og produsert i Arktisk råds arbeidsgrupper til å fremme Norges interesser internasjonalt, eller for å konstituere en bredere diskurs om Norge som en arktisk nasjon? Denne kunnskapen kan også være med på å skape en forståelse av at de arktiske statene befinner seg i et interessefellesskap og er med på å skape stabilitet i regionen (Rottem, 2019).

Samproduksjon er et nyttig teoretisk supplement til analysen vår, spesielt fordi Arktisk råd ikke er et rent vitenskapelig organ, men i tillegg består av en rekke 
representanter fra forvaltningen. Tilnærmingen er også nært koblet til hvordan kunnskapsproduksjonen er organisert (Sundqvist \& Hermansen, 2015). Hvordan hentes vitenskapelig ekspertise inn i arbeidsgruppen, hvem formulerer problemstillingene og utarbeider policyanbefalingene, og hva betyr dette for hvorfor og hvordan kunnskapen anvendes? Innsikt fra det man kan kalle lineære modeller, er relevant, men bør i mange tilfeller komplementeres med teorier som sier noe om hvordan kunnskap konstitueres og utvikles i samspill mellom forskjellige aktører og nivåer over tid.

Den siste faktoren inkludert i analysen har vi dermed valgt å kalle «organisering». Faktoren omhandler hvordan forholdet mellom forvaltning og forskningsmiljøene er organisert, og hvilke aktører som er involvert. Er dette forholdet mer eller mindre tilfeldig, eller har man klare formaliserte rutiner når det gjelder forskernes tilgang til relevante forvaltningsorganer, og er disse preget av en hierarkisk struktur eller mer eller mindre likestilte kommunikasjonslinjer? (Clark et al., 1998). Hvorvidt aktører som blir berørt av politiske tiltak, er involvert i prosessen, og om man har systemer for oppfølging av gitte prosjekter og tiltak, er også relevant (Clark et al., 1998). Oppsummert forventer vi dermed at de fire faktorene - vitenskapelig enighet og presisjon, økonomisk og politisk kontrovers, offentlig og politisk oppmerksomhet og organisering - legger føringer for om og hvordan kunnskap blir brukt.

I våre caser vil vi vise at det er stor variasion mellom arbeidsgruppene. For å studere hvordan vitenskap blir brukt, må vi ikke avgrense oss til et enkelt sett av analytiske verktøy, men anvende ulike modeller og teoretiske tilnærminger. Hver case vil ha ulike særtrekk, og det å finne en "grand theory» på betydningen av vitenskap er ikke formålstjenlig. Da mister vi nyansene.

Vinteren 2017-2018 gjennomførte vi 18 intervjuer med sentrale aktører (forskere, sekretariat og embetsverk) både i arbeidsgruppene (AMAP, CAFF og PAME) og i forvaltningen (Miljødirektoratet, Klima- og miljødepartementet [KLD], Nærings- og fiskeridepartementet og Utenriksdepartementet) for å belyse problemstillingen. Disse intervjuene ble supplert og oppdatert med seks nye intervjuer høsten $2019 .{ }^{2}$ Brorparten av intervjuobjektene har eller har hatt en sentral en rolle i de respektive arbeidsgruppene. Vinteren 2018 arrangerte vi i samarbeid med Klima- og miljødepartementet en workshop om Arktisk råd og nasjonal forvaltning. Innspill fra denne har også blitt brukt i artikkelen. I tillegg har vi innhentet og analysert tidligere relevante forskningsbidrag og evalueringer.

Artikkelen er strukturert på følgende måte: Først gir vi en generell introduksjon til Arktisk råd. Dette er nødvendig for å få en forståelse av rådets handlingsrom. Så går vi til det sentrale temaet for artikkelen: bruk av kunnskap og retningslinjer utarbeidet under Arktisk råd-paraplyen. I denne delen presenterer vi de tre nevnte arbeidsgruppene og diskuterer etablering og bruk av kunnskap basert på den analytiske inngangen ovenfor. Avslutningsvis oppsummeres relevante funn, og vi viser ulike måter kunnskap blir anvendt på.

\footnotetext{
${ }^{2}$ Ved referanser til intervjuene står arbeidsgruppen informanten er tilknyttet, og dato for intervju.
} 


\section{Arktisk råd - en introduksjon}

Som følge av store pågående klimaendringer har Arktis igjen fått en plass på den internasjonale dagsordenen. Høyere temperaturer og mindre is endrer rammebetingelsene for aktører med interesser i regionen. Teknologisk utvikling har samtidig gjort det mulig å utvinne ressurser i områder som tidligere var utilgjengelige. Den kommersielle aktiviteten øker, og de arktiske statene har alle ambisjoner om å være med på å forme det «nye» Arktis. Likevel er regionen i all hovedsak preget av politisk stabilitet og velfungerende forvaltningsregimer, og det er bred enighet om spillereglene. Blant de arktiske statene beskrives Arktisk råd som det viktigste internasjonale forumet for dialog og samarbeid om arktiske utfordringer og muligheter, og som en avgjørende arena for kunnskapsutvikling i og om en region i endring. Økt oppmerksomhet og interesse for Arktis har gitt betydelig utslag i rådets portefølje gjennom dets levetid. I 1996, da Arktisk råd ble etablert, var det iverksatt 30 prosjekter, og den internasjonale interessen for hva som foregikk i Arktis, var begrenset. Per 2020 er antallet prosjekter rundt 100. Parallelt har flere aktører vist interesse for det arbeidet som gjøres i Arktisk råd. Ut over seks organisasjoner fra arktiske urbefolkninger, som har status som faste deltakere, er det i skrivende stund 13 ikke-arktiske stater, 14 mellomstatlige og interparlamentariske organisasjoner og 12 interesseorganisasjoner med observatørstatus i Arktisk råd.

I den første perioden fra 1996 og fram til midten av 2000-tallet var størstedelen av arbeidet i Arktisk råd rettet mot forurensning. Det finnes høye nivåer av miljøgifter og tungmetaller i nord, og store deler av denne forurensningen føres fra sør til nord med hav- og luftstrømmer. Dette var i all hovedsak et lite sensitivt politisk spørsmål og traff også tiden, da en rekke miljøutfordringer var gjenstand for internasjonale forhandlinger. Temaet ble adressert i AMAPs første store rapport fra 1998, der arbeidsgruppen kartla miljøgifter i Arktis (AMAP, 1998). Siden den gang har arbeidsgruppene fortsatt å utarbeide en rekke rapporter som beskriver miljøutfordringer i nord. Tidlig på 2000-tallet fikk klimaendringene i Arktis større oppmerksomhet. Dette kom blant annet til syne i det mest omtalte vitenskapelige arbeidet gjort under Arktisk råd, Arctic Climate Impact Assessement (ACIA) (AMAP, CAFF \& IASC, 2005). $A C I A$ viste hvordan Arktis står i en særstilling når det gjelder klimaendringene. Rapporten konkluderte med at temperaturøkningen i Arktis har vært dobbelt så høy som det globale gjennomsnittet, noe som blant annet fører til nedsmelting av hav- og landis. De seneste årene har den sosioøkomiske utviklingen $\mathrm{i}$ nord fått økt oppmerksomhet på grunn av endringer i klima og den økte aktiviteten i kjølvannet av disse.

Rent praktisk er Arktisk råds organisering basert på en formannskapsmodell. Formannskapet roterer mellom de åtte statene som er faste medlemmer. Vanlig prosedyre er at en formannskapsperiode går over to år. Hovedarbeidet i selve rådet foregår på tre nivåer: ministernivå, embetsmannsnivå (Senior Arctic Official [SAO]) og arbeidsgruppenivå. Disse får igjen støtte fra sekretariatet som ble opprettet i 2013 i 
Tromsø. På ministermøtene i Arktisk råd fattes en erklæring og vedtak som signaliserer hvilken retning rådet skal gå i. Deltakelsen til de arktiske statenes utenriksministre gir disse erklæringene mer politisk tyngde. I forbindelse med ministermøtene bytter også statene formannskap. På ministermøtet lanserer det nye formannskapslandet sine ambisjoner, og her har altså statene muligheten til å sette et personlig avtrykk. Det daglige arbeidet foregår likevel lenger ned i strukturen. På embetsmannsnivå møtes SAO-ene (Senior Arctic Officials) minst to ganger i året. De fungerer dermed som bindeleddet mellom ministernivået og arbeidsgruppenivået. Det er de som på vegne av sine lands regjeringer har det daglige ansvaret for å følge opp rådets arbeid. Det er likevel i arbeidsgruppene ${ }^{3}$ mesteparten av arbeidet i Arktisk råd pågår. Her sammenstilles kunnskap om tilstanden og utviklingen i Arktis, i tillegg til at anbefalinger og retningslinjer for å møte utfordringene og mulighetene formuleres. Samtidig er det viktig å påpeke at Arktisk råd $i k k e$ er en internasjonal traktatfestet organisasjon som kan ta bindende avgjørelser. Rådet kan ikke operere uavhengig av statene som etablerte det, og det kan ikke sanksjonere stater som ikke følger anbefalinger fra arbeidsgruppene. I så måte betegnes rådet ofte som en institusjon basert på «soft law», hvis beslutninger kun er politisk bindende.

\section{Arbeidsgruppene og Arktisk råd}

Hver arbeidsgruppe har sin egen historie og ulike porteføljer. De har likevel noen fellestrekk. I alle arbeidsgruppene sitter det representanter fra nasjonal forvaltning. De har et mer eller mindre spesifikt mandat som de opererer etter, et formannskap (som også roterer mellom statene) og et styre eller en styringskomité som støttes av et sekretariat. Alle vedtak krever konsensus, slik som i resten av rådets arbeid. Det er også viktig å understreke at arbeidsgruppene får sitt mandat fra ministermøtene og fra SAO-ene, men hvor spesifikt dette mandatet er, varierer, både mellom arbeidsgruppene og temaene de behandler.

De tre arbeidsgruppene vi undersøker her - AMAP, CAFF og PAME - kan sammenlignes fordi de har giennomført store vitenskapelige og ambisiøse tilstandsvurderinger (assessments) innenfor sine ansvarsområder. Her er arbeidsgruppene helt avhengig av å hente inn vitenskapelig ekspertise. Tilstandsvurderingene har fått oppmerksomhet både i og utenfor Arktis, og de inneholder typisk anbefalinger til oppfølgingsaktiviteter. Arbeidsgruppene vil først bli behandlet separat med en kort presentasjon av historikk og fokusområder. Vårt hovedanliggende er likevel å si noe om hvordan kunnskap sammenstilt i disse arbeidsgruppene, blir anvendt, og hvorfor kunnskap om ulike arktiske utfordringer blir anvendt på ulike måter.

\footnotetext{
${ }^{3}$ Disse er CAFF, AMAP, PAME, EPPR, ACAP og SDWG. I slutten av artikkelen finnes det en liste over forkortelser.
} 
AMAP - en introduksjon

AMAP, som har sitt sekretariat i Troms $ø,{ }^{4}$ blir ofte trukket fram som den viktigste arbeidsgruppen. Den har det største budsjettet av alle arbeidsgruppene og har i Arktisk råd-sammenheng et nokså omfattende sekretariat med omtrent syv ansatte. Finansieringen av ulike prosjekter har samtidig vært nokså stabil. Arbeidsgruppens hovedmandat er å overvåke det arktiske miljøet, økosystemer og befolkningsgrupper. Den skal også gi råd til beslutningstakere basert på den mest oppdaterte kunnskapen om hvordan forurensning og skadelige virkninger av klimaendringer bør takles. Statene i Arktisk råd får altså jevnlige vitenskapelige rapporter og sammendrag som oppsummerer resultatene fra AMAP, og der arbeidsgruppen kommer med anbefalinger av varierende politisk tyngde.

Da AMAP ble opprettet, var miljø det viktigste arbeidsfeltet. ${ }^{5}$ Ulike kilder til forurensning i Arktis var i søkelyset, blant dem langtransporterte (persistente) organiske miljøgifter (POP-er), tungmetaller og radioaktivitet. ${ }^{6}$ Lokale kilder til forurensning, som olje og gass, var også på agendaen. Arbeidet på klimasiden startet først opp under arbeidet med Arctic Climate Impact Assessement (ACIA) (publisert i 2004-2005), som ble ledet av AMAP (AMAP, CAFF \& IASC, 2005). Arbeidet med ACIA ble fulgt opp giennom Snow, Water, Ice and Permafrost in the Arctic (SWIPA) (AMAP, 2011). Den siste SWIPA-rapporten ble publisert i 2017 med bidrag fra over 90 forskere, og den har søkelyset på endringer i isforhold (land og vann) og konsekvensene av disse endringene, og denne rapporten ble igjen oppdatert i 2019 (AMAP, 2019). De seneste årene har også arbeidet med kortlevde klimadrivere stått sentralt samt tilstandsvurderinger av regional tilpasning i Arktis (se AMAP, 2015a). Tilpasningsfokuset er særlig tydelig i prosjektet Adaptation Actions for a Changing Arctic (AACA), som leverte sine siste rapporter i 2017 (se AMAP, 2017a).

Overordnet kan vi si at AMAP har to hovedpilarer: klima og miljø, ${ }^{7}$ men at det også har skjedd en stadig utvidelse av AMAPs mandat. Fra nokså avgrenset oppmerksomhet på forurensning av det arktiske miljøet til klimaendringer (både utslippsreduksjon og tilpasning), til i større og større grad å kartlegge sosioøkonomiske konsekvenser av denne utviklingen. Arbeidsgruppen har gitt innspill til ulike internasjonale konvensjoner. Særlig har arbeidet med FNs miljøprogram (Rottem, 2019) på langtransporterte miljøgifter (POP-er) og kvikksølv - samt innspill til det

\footnotetext{
${ }^{4}$ AMAPs sekretariat ble flyttet fra Oslo til Tromsø i 2018 og er dermed samlokalisert med Arktisk råd-sekretariatet.

${ }^{5}$ Allerede i den bredt anlagte rapporten om forurensning i Arktis fra 1998 var likevel klimaendringer i Arktis adressert (AMAP, 1998).

${ }^{6}$ For en kort gjennomgang av AMAPs produksjon innen dette feltet, se https://www.amap.no/ about/strategy-and-workplan. For en oversikt over rapporter, se https:/www.amap.no/documents ${ }^{7}$ Vi finner likevel ofte et samspill mellom klimatiske endringer og spredning og opptak av miljøgifter, noe som har blitt adressert i flere AMAP-rapporter. Se for eksempel AMAP (2003) og AMAP (2009).
} 
globale klimaregimet generelt og det internasjonale klimapanelet (Intergovernmental Panel on Climate Change [IPCC]) spesielt - vært viktig.

AMAP og bruk av kunnskap

I enhver analyse av forholdet mellom vitenskap og politikk er en vurdering av statusen på foreliggende kunnskap et naturlig utgangspunkt. Det overordnede bildet viser at AMAP gjennom tre tiår har lagt et tungt vitenskapelig grunnlag for sin virksomhet. De jevnlige tilstandsvurderingene av for eksempel POP-er, kvikksølv, radioaktivitet og klima har høy vitenskapelig status. All kunnskapssammenstilling i AMAP går også igjennom fagfellevurdering før publisering (AMAP, 2015b). Kartlegging av for eksempel miljøgifter har samtidig en lang historie, og tilstandsvurderingene og forskningsgrunnlaget er entydig nok til å komme med velbegrunnede anbefalinger.

Et godt eksempel på dette er arbeidet med å kartlegge persistente organiske miljøgifter (POP-er) i Arktis. Dette har stått sentralt i AMAPs arbeid fra arbeidsgruppen ble etablert i 1991. I den forbindelse har også arbeidsgruppen kommet med anbefalinger om hvilke POP-er som bør reguleres internasjonalt. Norske myndigheter har for eksempel nominert tre stoffer til Stockholm-konvensjonen de siste ti årene, og man har vært helt avhengig av kunnskap fra blant annet AMAP. Bærende i arbeidet med POP-er har vært å finne stoffer hvor kunnskapsstatusen har vært entydig og presis (Rottem, 2017). Det har vært bred enighet om at de stoffene som har blitt nominert, har egenskaper som gjør dem til POP-er, og at de er en fare for miljø og helse. ${ }^{8}$ Vi finner også bred vitenskapelig enighet om at disse bør reguleres. Arbeidsgruppen har kommet med konkrete anbefalinger om tiltak.

Når det gjelder klima, den andre hovedpilaren til AMAP, er bildet mer sammensatt. Til tross for bred vitenskapelig enighet om at klimaendringer er menneskeskapt, er det vitenskapelige grunnlaget adskillig mer fragmentert (Andresen et al., 2017). De ulike framskrivningene til IPCC er et kjerneeksempel her. Kildene til problemene er også i mye større grad differensiert, noe som gjør det vitenskapelige arbeidet mer komplekst og delvis preget av større usikkerhet. Tiltaksporteføljen er også mye større. Dette har igjen betydning for hvor spissede anbefalinger arbeidsgruppene kan komme med, noe som kommer til syne i for eksempel arbeidet med klimatilpasning. Rapporten Adaptation Actions for a Changing Arctic (AACA) fra 2017 er for eksempel i større grad en kartlegging av tilpasningsutfordringer og motstandsdyktighet i arktiske lokalsamfunn og har mindre oppmerksomhet på konkrete tiltak. Norsk miljøforvaltning har dermed som ambisjon å bruke denne kunnskapen som beslutningsgrunnlag, og mindre som en oppskrift for å løse et problem (AMAP, intervju 17.10.19).

\footnotetext{
${ }^{8}$ I arbeidet med Stockholm-konvensjonen, som i utgangspunktet regulerte tolv POP-er, var det liten grad av vitenskapelig uenighet om at stoffene var skadelige for mennesker og miljø (Downie, 2012).
} 
Tilbakevendende i diskusjonen om bruk av AMAP-kunnskap er dermed grad av presisjon i den kunnskapen og de anbefalingene som ofte springer ut av denne. De dokumentene som tydeligst viser denne dimensjonen, er de såkalte summary for policymakers. I den avsluttende delen av disse korte vitenskapelige sammendragene fra arbeidsgruppene finner vi ofte mer eller mindre spissede konklusjoner og anbefalinger. Igjen er mønstret det samme. Når det gjelder miljøgifter, er anbefalingene tydelige. Det er nokså klart hvilke tiltak som må eller bør giøres. Et eksempel er rapporten Arctic Pollution Issues 2015, hvor en klar anbefaling er at alle de arktiske statene må ratifisere Stockholm-konvensjonen, som regulerer POP-er, og Minimata-konvensionen, som regulerer kvikksølv (AMAP, 2015c). Vi ser også at man tidvis gir eksplisitte anbefalinger om å regulere enkeltstående miljøgifter (se AMAP, 2017a). SWIPA-rapporten, som altså omhandler klimaendringer og tilpasning til disse, viser et mer sammensatt bilde. Her er anbefalingene ofte bredt formulert. Vi finner enkelte eksempler hvor arbeidsgruppen anbefaler styrking av internasjonalt samarbeid: "The Arctic states, permanent participants, and observers to the Arctic Council should individually and collectively lead global efforts for an early, ambitious and full implementation of the Paris COP21 Agreement, including efforts to reduce emissions of short-lived climate forcers" (AMAP, 2017b). Anbefalingene er likevel oftere mindre presise, for eksempel: «The Arctic Council should continue its efforts to monitor, assess, and understand Arctic climate change and its implications" (AMAP, 2017b). Det er også viktig å understreke at vi ser at AMAP har to roller i denne sammenhengen: å øke kunnskapen om utviklingen i Arktis og å komme med politiske anbefalinger om ulike tiltak. Innspillene til for eksempel IPCC er i stor grad rent vitenskapelige, hvor formålet er å øke kunnskapsgrunnlaget og dermed beslutningsgrunnlaget for politiske aktører, ikke å komme med endelige anbefalinger. På miljøfeltet er kartlegging avgjørende, men her ser vi også et større handlingsrom for å foreslå konkrete tiltak. Det viktigste poenget er at graden av presisjon i de anbefalingene vi finner i AMAPs rapporter, varierer. Det skyldes ikke bare statusen på foreliggende kunnskap, men også bruken av den. Rene naturvitenskapelige målinger og tilstandsvurderinger av enkeltstående miljøgifter vil automatisk kunne utledes til konkrete tiltak. Vi kan også gjøre et skille mellom ulike typer anbefalinger, for eksempel om direkte regulerende tiltak og behov for mer forskning på gitt felt og mellom konkrete tiltak og det å sammenstille kunnskap som skal gi input til andre internasjonale politiske prosesser, hvor vedtak skal treffes. Tilpasningsfeltet, som klimafeltet generelt, er tverrsektorielt, og det kan også argumenteres for at kunnskapsgrunnlaget er mer fragmentert og tidvis mer uklart. Arbeidet med miljøgifter (herunder kvikksølv og POP-er) og klima har likevel en rekke fellestrekk. AMAPs bidrag innenfor disse to feltene er i stor grad internasjonalt.

Hvis vi går over til variabelen grad av økonomisk og politisk kontrovers, ser vi også et tydelig skille mellom klimafeltet og miljøfeltet. Klimafeltet er preget av en mye større grad av politisk og økonomisk kontrovers. Sagt enkelt: Det å takle og regulere miljøgifter i Arktis er mindre krevende enn en storstilt omlegging av verdens energistruktur. Vi 
kan igjen bruke AMAPs kunnskapsammenstilling om POP-er og Norges anvendelse (gjennom nominasjon av nye POP-er) av denne kunnskapen som eksempel. Utgangspunktet for å iverksette en nominasjonsprosess er at Klima- og miljødepartementet har en høy profil på miljøgifter, noe som også viser seg i tildelingsbrevene (Klima- og miljødepartementet, 2016, 2018) til Miljødirektoratet fra Klima- og miljødepartementet. Etter en slik «bestilling» vil Miljødirektoratet iverksette et arbeid med å kartlegge hvilke stoffer som kan være aktuelle for en nominasjon. Ser vi på den nasjonale politiske debatten, har regulering av POP-er vært lite kontroversielt. Det samme kan man ikke si om klimafeltet. Poenget er at det ikke har vært politisk kontroversielt å arbeide for å styrke av Stockholm-konvensjonen, som regulerer POP-er. Det har heller forholdt seg slik at den politiske innblandingen har vært liten (Rottem, 2017). Den økonomiske dimensjonen er selvsagt nært koblet til det politiske. Igjen finner vi et nokså entydig bilde: Ingen av stoffene Norge har nominert, blir produsert nasjonalt. Norske kommersielle aktører har dermed i liten utstrekning motsatt seg regulering av de stoffene Norge har nominert. Igjen kan vi se på klimafeltet som en direkte kontrast til dette. Arbeidet med en nominasjon er imidlertid ressurskrevende, og man er dermed avhengig av en direkte eller indirekte politisk aksept for å innta en slik lederrolle i nominasjonen av nye stoffer. Bildet bør altså utvides.

Graden av offentlig og politisk oppmerksomhet rundt de feltene AMAP jobber med, må også vurderes. En forventning vil ofte være at jo større politisk oppmerksomhet, desto større sjanse for at kunnskap blir spilt inn i nasjonale miljøforvaltningsprosesser og internasjonale forhandlinger. Det er ikke gitt at det er slik. Vi kan igjen se på AMAPs arbeid med klima. Både på nasjonalt og internasjonalt nivå er klima høyt på den politiske og offentlige dagsordenen. Det betyr at forvaltningen stadig utsettes for ny innsikt og komplekse politiske problemstillinger som gir et økt press på ressursene. Hvis vi igjen ser på eksemplet med POP-er, har diskusjonene om de enkelte stoffene ikke blitt løftet høyt, verken på den offentlige eller den politiske agendaen. Nominasjonen av nye POP-er er likevel uløselig knyttet til forestillingen om Norge som en miljønasjon (Berntsen, 2011). At enkeltstoffene går under radaren, kan giøre det lettere å være miljøvennlig idet man slipper unødig «støy» i det faglige arbeidet. En annen sentral dimensjon i denne sammenhengen er den høye aktualiteten Arktis har i norsk offentlighet. Norske myndigheter har de seneste ti år publisert en rekke dokumenter som understreker dette (Utenriksdepartementet, 2011; Regjeringen, 2014, 2017). Denne oppmerksomheten har funnet sted uavhengig av regjeringens partipolitiske sammensetning. Forskning på miljøgifter i regionen er en del av dette bildet. Mye tyder på at norsk miljøforvaltning på dette feltet i stor grad er basert på tillit og en felles forståelse av at forskning i Arktis er viktig. AMAPs arbeid med POP-er har dermed fått gjennomslag. Det skyldes bred vitenskapelig enighet, det har verken vært politisk eller økonomisk kontroversielt å være miljøvennlig, og feltet er samtidig innlemmet $\mathrm{i}$ en positiv politisk og offentlig diskurs om et giftfritt nord.

En analyse av AMAP som kunnskapssammenstiller og effektene av dette kan likevel ikke begrenses til en lineærmodell om bruk av forskning som skissert ovenfor. 
Vi må gå et steg tilbake å spørre oss: Hvem formulerer problemstillingene i AMAPs arbeid? Hvem utarbeider policyanbefalinger? Bruker forvaltningen kunnskapsproduksjon for å fremme "norske interesser»? I arbeidet med klima- og miljøutfordringer i Arktis er det særlig tre nasjonale aktører som står sentralt. Først og fremst er det Klima- og miljødepartementet, som formelt har det siste ordet, og som legger de overordnede politiske føringene for arbeidet. Den viktigste aktøren innenfor saksfeltet er likevel Miliødirektoratet. Miljødirektoratet har de seneste år ansatt medarbeidere med god fagkompetanse innenfor sine respektive fagfelt, men har ikke egne forskere ansatt i sin stab. Direktoratet er dermed helt avhengig av formell og uformell kontakt med nasjonale og internasjonale forskningsmiljøer for å skaffe seg den mest oppdaterte informasjonen. Det er i denne sammenhengen AMAP har spilt en sentral rolle som kunnskapssammenstiller. AMAP er sammensatt av delegasjonsledere fra de åtte arktiske statene og primært fra miljøforvaltningen. De har igjen fått sine nasjonale og politiske føringer samt retningslinjer fra Arktisk råd gjennom SAO- og ministernivå (Arktisk råd, 2013). På overordnet nivå har AMAPs arbeid vært preget av kontinuitet og begrenset direkte politisk innblanding. Dette viser seg blant annet ved at arbeidet med å kartlegge forurensning og miljøgifter i Arktis har en nesten 30 år lang historie, og arbeidet med klima har pågått i 20 år. Det kan være flere grunner til denne kontinuiteten, for eksempel enkeltpersoners engasjement og stabil finansiering fra blant annet norsk miljøforvaltning (Klima- og miljødepartementet og Miljødirektoratet). Alle medlemsstatene i Arktisk råd har sett på dette som en av grunnpilarene i det arktiske samarbeidet, noe som også har gjort det mulig for Norge å kanalisere ressurser inn i dette arbeidet (Rottem, 2019). Dette kan igjen underbygge oppfatningen om et arktisk interessefellesskap og dermed en stabil orden i regionen. Vi bør likevel gå et steg lenger og se hvordan arbeidet med nye og pågående tilstandsvurderinger foregår. Hvordan hentes for eksempel vitenskapelig ekspertise inn i arbeidsgruppen? I utgangspunktet foregår dette på følgende vis: Statene gjennom delegasjonslederen nominerer eksperter (forskere) med en finansiell forpliktelse om å sette av tid og ressurser til å arbeide med en gitt rapport eller tilstandsvurdering. De nominerte ekspertene vil dermed etablere en ekspertgruppe. I forlengelsen av dette vil ekspertene igjen kunne rekruttere nye eksperter (AMAP, 2015b). Og som en av våre informanter sa: «Da kan det gå litt av seg selv» (AMAP, intervju 10.11.19). I AMAP har dette de seneste årene aldri vært utpreget kontroversielt eller politisert. I tillegg kan både observatørene (herunder stater, IGO-er og NGO-er) nominere eksperter. I arbeidet med å formulere problemstillingene vil de nasjonale miljøforvaltningene vurdere hva som er forvaltningsrelevant, og deretter trekke inn vitenskapelig ekspertise som kan vurdere de gitte problemstillingene. Etter at dagsordenen er satt og overordnede problemstillinger er formulert, er arbeidet $\mathrm{i}$ stor grad drevet av ekspertene (AMAP, intervju, 10.11.19). I denne sammenhengen er det også viktig å understreke at Arktisk råds arbeidsgrupper ikke er vitenskapsprodusenter i snever forstand, men heller kan defineres som kunnskapssammenstillere. Når en tilstandsvurdering eller en vitenskapelig rapport er ferdig, vil man 
formulere et sett av viktige funn og anbefalinger i en "summary for policymakers». Dette vil ledes av delegasjonslederne i samarbeid med forskerne. AMAP vil da bruke en "science writer» som tydeliggjør budskapet. Et slikt utkast vil igjen bli diskutert av delegasionslederne. Her ligger det en mulighet for kontrovers, og delegasjonslederne vil være bevisst hva som er politisk sensitivt. I vår artikkel er det ikke rom for å gå dypt inn i enkeltstående forhandlinger om formuleringene av disse anbefalingene, men et funn er at i AMAP er dette arbeidet i stor grad ekspertdrevet og preget av lite kontrovers. At arbeidet i stor grad er ekspertdrevet, gir også tilstandsvurderingene nødvendig legitimitet. Her er det likevel rom for ytterligere forskning på enkeltstående rapporter og felt og enkeltstaters posisjonering i dette arbeidet. At forvaltningen etterspør kunnskap som er relevant for dem i deres daglige arbeid, er med på å konkretisere ulike behov. Det er ikke slik at forvaltningen (og dermed ofte indirekte det politiske nivået) leter etter relevant kunnskap, men det vi ser, er at delegasjonslederne «bestiller» kunnskap, noe man ville kunne forvente styrker relevansen og dermed muligheten for bruk av denne sammenstilte kunnskapen.

En foreløpig konklusion er at AMAP har hatt stor suksess med sitt arbeid på miljøgifter og tungmetaller. Når det gjelder POP-er, har denne aktiviteten også ført til nominasjonen av ytterligere stoffer under Stockholm-konvensjonen. Både for POP-er og miljøgifter generelt har forholdene ligget til rette for bruk av arktisk kunnskap. Vi kan tegne et lignende bilde når det gjelder kvikksølv (Platjouw et al., 2018). Imidlertid har arbeidet med klima (herunder utslippsbegrensninger og tilpasning) vært mer krevende. Det er ulike grunner til dette. Først og fremst er klimafeltet mer bredt, og det trengs derfor en bredere tiltaksportefølje på tvers av ulike sektorer. Det er altså vanskeligere å formulere presise og konkrete anbefalinger, samt å «overføre» kunnskap som vil kunne føre til konkrete tiltak. Hvis vi ser på samproduksjonen av forskning innenfor de to feltene, er likevel likhetene flere enn forskjellene. Selve arbeidet med å sammenstille kunnskap gjennom tilstandsvurderinger har vært lite kontroversielt eller politisert. Så kan man jo spørre seg hvorfor det er sånn. Et mulig svar er at Arktisk råd kun formulerer politisk bindende anbefalinger, og det er dermed mindre «farlig» å tilslutte seg disse. Vi bør likevel se på de andre arbeidsgruppene for å utfylle dette bildet.

\section{CAFF - en introduksjon}

Hovedarbeidet med biologisk mangfold finner sted i CAFF, som betjenes av et selvstendig sekretariat med fem medarbeidere i Akureyri på Island. Biologisk mangfold er likevel et tverrgående hensyn for Arktisk råds aktiviteter, og CAFF har derfor samarbeidet med de fleste av de andre arbeidsgruppene under Arktisk råd. CAFF var tenkt som et forum for forskere, urfolk og naturforvaltere som skulle sette arktisk biologisk mangfold på dagsorden. Ut over samarbeidet om mer effektiv forskning var formålet også å beskytte det arktiske økosystemet mot menneskelige trusler, blant annet gjennom å utvikle effektiv lovgivning og praksis for forvaltning av planter, dyr og levesteder og å bidra til miljøkonsekvensvurderinger (CAFF, 1993). CAFF gikk dermed ut over 
ren kunnskapsoppbygging og la også opp til forvaltnings- og lovgivningsmessig samarbeid. En tidlig prioritet for CAFF var for eksempel å skape et panarktisk nettverk av verneområder ("Circumpolar Protected Areas Network», CPAN) (CAFF, 1996). Dette arbeidet stoppet dog reelt i 2004 (se også under), og fra da av rettet CAFF sin innsats mot kunnskapsoppbygging. CAFF har samtidig fra starten knyttet sin regionale innsats til oppfølging av FNs konvensjon om biologisk mangfold (Biodiversitetskonvensionen, CBD) og andre globale instrumenter for naturbeskyttelse.

CAFF var, sammen med AMAP og International Arctic Science Committee (IASC), medutgiver av Arctic Climate Impact Assessment (ACIA) i 2004-2005. Den ble et viktig grunnlag for CAFFs arbeid fram til i dag (AMAP, CAFF \& IASC, 2005). Ut over at $A C I A$ for første gang satte søkelyset på klimaendringer som den alvorligste trusselen mot arktisk biologisk mangfold, gjorde $A C I A$ også oppmerksom på den manglende kunnskapen om de arktiske økosystemene og deres funksjon. Dette medvirket til at CAFF endret tilnærming fra å være mest opptatt av arter og deres levesteder til å rette oppmerksomheten på hele økosystemer, noe som samtidig var i harmoni med FNs Millennium Ecosystem Assessment, som kom samme år (FN, u.å.). ACIAs anbefalinger medvirket også til at CAFF utviklet "Circumpolar Biodiversity Monitoring Program» (CBMP), et internasjonalt nettverk av forskere, regjeringer, urbefolkningsorganisasjoner og naturverngrupper som arbeidet sammen for å harmonisere og integrere overvåkningen av Arktis' levende ressurser (CAFF \& CBMP, 2018). Tilstandsrapporter for marin biodiversitet og biodiversitet i ferskvann ble publisert i henholdsvis 2017 (CAFF, 2017a) og 2019 (CAFF, 2019a).

CAFF som et arktisk forum for vitenskapelig samarbeid og kunnskapsoppbygging nådde sitt foreløpige høydepunkt med utgivelsen av evalueringen av det biologiske mangfoldets tilstand i Arktis, Arctic Biodiversity Assessment (ABA) i 2013 (CAFF, 2013). $A B A$ er et svært ambisiøst og anerkjent prosjekt med stor vitenskapelig tyngde. Det har vært mulig for $A B A$ å omslutte hele det store problemkomplekset som inngår i begrepet biologisk mangfold. I tillegg til å kartlegge status og trender for økosystemer og arter analyserer $A B A$ både de underliggende og direkte årsakene til forverringen. Tilstandsvurderingen analyserer hva dette betyr for både økosystemets funksjon i seg selv, og for de tjenestene økosystemene gir til befolkningen i Arktis. Den diskuterer også hvilke tiltak som er nødvendige for å reversere utviklingen. I tillegg til den fagfellevurderte vitenskapelige rapporten omfatter $A B A$ en indikatorrapport, en vitenskapelig sammendragsrapport, en rapport om biologisk mangfold $\mathrm{i}$ forbindelse med is og et sammendrag for beslutningstakere med anbefalinger til oppfølging.

Det mer konkrete og håndgripelige arbeidet som kjennetegnet CAFF i starten, med søkelys på arter og bestander, har likevel fortsatt også etter at CAFF fikk en mer økosystembasert tilnærming gjennom blant annet "Arctic Species Trend Index» (ASTI) (CAFF, u.å.), CAFFs ekspertgrupper for flora ${ }^{9}$ og sjøfugler ("CBird») (med

\footnotetext{
${ }^{9}$ For mer info se https://www.caff.is/flora-cfg
} 
internasjonale strategier og handlingsplaner for truede arter som ærfugl, lomvi og ismåke.) ${ }^{10}$ samt "Arctic Migratory Birds Initiative» (AMBI) (CAFF, 2015b).

CAFFs siste større initiativ (i samarbeid med PAME) er en strategi og handlingsplan for bekjempelse av fremmede arter i Arktis (Arctic Invasive Alien Species Strategy and Action Plan, ARIAS) (CAFF, 2017b). Fremmede arter har Arktis hittil vært forskånet for, men de forventes å komme i takt med varmere temperaturer og $ø$ kt menneskelig aktivitet. Handlingsplanen beskriver tiltak, som først og fremst Arktisk råd skal iverksette for å beskytte Arktis mot de negative virkningene av fremmede arter. I mindre grad inneholder den tiltak rettet mot de enkelte landene innenfor og utenfor Arktis.

\section{CAFF og bruk av kunnskap}

CAFF lever i høy grad opp til Arktisk råds formål om å levere førsteklasses vitenskapelig kunnskap om det arktiske miljøet - i dette tilfellet om tilstanden til det arktiske biologiske mangfoldet og de faktorer som påvirker det. CBMP konsentrerer seg om Arktis' store økosystemer, ferskvann, kyst, hav og land og har fătt status som den arktiske arm av det globale overvåkningsnettverket GEO BON. ${ }^{11}$ CBMPs tilstandsrapporter inneholder samtidig en rekke anbefalinger til oppfølgende overvåkningsoppgaver og koordinering av disse, som i høy grad er relevante for naturovervåkningen i de enkelte arktiske statene. Dessuten har CAFF bygd opp datahåndteringssystemet "Arctic Biodiversity Data Service» (ABDS) for å lette tilgangen til informasjon for forskere, beslutningstakere, lokale samfunn, internasjonale partnere og så videre.

CAFFs arbeid har vitenskapelig tyngde, og det anvendes og siteres i internasjonal sammenheng. Arbeidet inngår som regionale bidrag til globale rapporter om tilstanden av biologisk mangfold. Det er bred vitenskapelig enighet om utfordringenes karakter og omfang, men også om at løsningene av dem er uhyre komplekse og avhengig av en rekke faktorer, som i stor utstrekning ligger utenfor de enkelte arktiske staters kontroll. Det krever altså handling utenfor Arktis, men i andre tilfeller mellomstatlige handlinger innenfor Arktis, for eksempel etableringen av verneområder på tvers av grenser. Det siste krever bindende avtaler mellom en eller flere arktiske stater om begrensninger i bruken av arealer under statenes nasjonale jurisdiksjon.

Som tilfellet ofte er for Arktisk råds vitenskapelige utredninger, inneholder CAFFs utredninger ofte anbefalinger til oppfølgende tiltak. Dog gjelder likevel dette i mindre omfang for CAFF enn for andre arbeidsgrupper, og til sammenligning er CAFF-anbefalingene typisk mer generelle og mindre spisse og som oftest rettet mot oppfølging av vitenskapelig arbeid. De viktigste politikkrelaterte anbefalinger er de 17 anbefalingene fra ABAs Report for Policy Makers. Anbefalingene er generelt brede, og de spesifiserer ikke hvem de er adressert til. Et eksempel er anbefaling 3: "Advance and advocate ecosystem-based management efforts in the Arctic as a framework for

\footnotetext{
${ }^{10}$ For mer info se https://www.caff.is/seabirds-cbird

${ }^{11}$ For mer info se http://geobon.org/
} 
cooperation, planning and development». ${ }^{12}$ I oppfølgingshandlingsplanen Actions for Arctic Biodiversity 2013-2020 er ABA-anbefalingene som hovedregel rettet til Arktisk råd som helhet og skal implementeres av både CAFF og andre arbeidsgrupper under Arktisk råd, mens få av anbefalingene vil kreve handlinger fra nasjonale myndigheter, internasjonale organisasjoner og andre aktører (CAFF, 2015a).

De overordnede temaene for CAFF - biologisk mangfold, økosystemer og økosystemtjenester - egner seg mindre til konkrete, presise retningslinjer for nasjonal handling enn temaer under andre arbeidsgrupper med mer spesifikke problemstillinger som kortlevde klimastoffer, forurensningsbekjempelse, oljesøl med mer. Det skyldes CAFFs valg av en bred, sektorovergripende og økosystembasert forståelse av sin rolle. Et eksempel er CAFFs oppfølging av ABA-anbefaling 3 for å innlemme hensyn til biologisk mangfold i industrielle og andre aktiviteter. Resultatet var ikke et sett retningslinjer, som oppfølgingshandlingsplanen ellers foreslår, men i stedet en casestudie av en enkelt næring, nemlig gruvedrift (CAFF, 2019b). Omfang, kompleksitet og den resulterende tiltaksporteføljen kan dermed sammenlignes med AMAPs arbeid med klima, nevnt ovenfor. Den brede sektorovergripende tilnærmingen gir også større «risiko» for konfrontasjon med politisk sensitive spørsmål. Eksempler på disse er, akkurat som for PAME (omtalt nedenfor), fiskeri og verneområder.

Som omtalt ovenfor er graden av presisjon en viktig parameter for om retningslinjer og anbefalinger har virkning som «soft law». CAFF-anbefalingenes generelle form kan føre til at det er begrenset politisk og offentlig oppmerksomhet om anbefalingene, og at det blir vanskelig å iverksette mekanismer for overvåkning av den nasjonale oppfølgingen. Fordi CAFFs anbefalinger, basert på best tilgjengelig kunnskap, verken er formulert eller oppfattes som forpliktende for statene, er det vanskelig å påvise en effekt av dem på nasjonal miljøforvaltning. En annen grunn til at effekten er vanskelig å få øye på, hvis vi ser til Norge, er at Norge, som et ressurssterkt og miljøbevisst land, ofte er "foran» CAFF når det gjelder nasjonale tiltak. Et sentralt poeng er også at de som i forvaltningen jobber med internasjonalt (herunder arktisk) samarbeid, sjelden er de samme som de som arbeider med nasjonal oppfølging. I enkelte tilfeller arbeider likevel personer i forvaltningen med begge deler, og de bygger dermed en bro mellom CAFF-arbeidet og nasjonal forvaltning.

På de områdene hvor CAFF fortsatt jobber med spesifikke og mer «håndgripelige» emner, som å utarbeide handlingsplaner for truede sjøfuglarter, er det lettere å oppnå tydelige anbefalinger og dermed en direkte relevans for det enkelte land, og nettopp i CAFFs arbeid med sjøfugl ses nok den mest direkte effekten av CAFF på norsk forvaltning. Norske CAFF-aktører peker for øvrig på anbefalingene i den nylig utsendte strategien og handlingsplanen om fremmede arter som et nyttig verktøy for

\footnotetext{
12 Med tillegget: «This includes an approach to development that proceeds cautiously, with sound short and long-term environmental risk assessment and management, using the best available scientific and traditional ecological knowledge, following the best environmental practices, considering cumulative effects and adhering to international standards.»
} 
norsk politikk på området, og de ser dette vedtaket som et tegn på at CAFF beveger seg i mer handlingsorientert retning (CAFF, intervju 16.11.17).

Biologisk mangfold i Arktis får offentlig og politisk oppmerksomhet i Norge om enn ikke i samme grad som klima. Det inngår dermed med stor vekt i regjeringens handlingsplan for biologisk mangfold fra 2016, og det er nærliggende at en del av de statusopplysningene som inngår i handlingsplanen om Arktis, stammer fra CAFF-utredninger. Det henvises likevel ikke til det (Klima- og miljødepartementet, 2015). CAFFs utredninger identifiserer mangler i naturovervåkning og forskning og kan dermed fungere som løftestang for forskning og bevilgninger til forskning i Norge. Ut over det er effekten av CAFFs vitenskapelige utredninger vanskelige å måle på nasjonalt plan, og den må til en viss grad betegnes som indirekte $\mathrm{i}$ form av at CAFF og dens tekniske ekspertgrupper er møtesteder for fagfolk, som tar sine erfaringer fra møtet med utenlandske kollegaer hjem og lar dem inngå i sitt nasjonale arbeid.

Som påpekt av CAFF-aktører skjer CAFFs kunnskapsoppbygging om arktisk biologisk mangfold av hensyn til hele Arktis - ikke bare av hensyn til det enkelte arktiske land. I den forbindelse er Norge, som et ressurssterkt arktisk land, i mange tilfeller en stor bidragsyter til CAFF med kunnskap, som altså ikke er ny for Norge når den presenteres i CAFF-regi. Hovedbildet er at norsk forvaltning bruker CAFF som kunnskapsaktør til å styrke det internasjonale samarbeidet om biologisk mangfold, både i nord og globalt. Og igjen er dette med på ikke bare å dokumentere eksisterende fellesinteresser mellom de arktiske statene, men også på å skape disse.

Norge arbeider likevel i CAFF for at arbeidsgruppens kunnskapsoppbygging blir så relevant som mulig for norsk forvaltning, og det finnes da også eksempler på mer direkte kunnskapsoverføring til norsk forvaltning, som igjen iverksetter tiltak. CBMP-overvåkningsarbeid av ferskvannsøkosystemer viste for eksempel at det er behov for bedre overvåkning av nordnorske ferskvannsområder.

Også i når det gjelder CAFF, er det nødvendig å vurdere hvordan arbeidet med kunnskapsproduksjon og oppfølgingsanbefalingene er organisert og faktisk foregår, for å forstå effektene av arbeidet fullt ut. Som tilfellet er for AMAP og PAME, er CAFF sammensatt av delegasjonsledere fra de åtte arktiske statene. Den norske delegasionslederen kommer fra Miløødirektoratet (som tilfellet er for AMAP, men i motsetning til PAME, der representanten kommer fra Klima- og miljødepartementet). Flere av delegasjonslederne i de andre landene er også typisk fra den tekniske eller faglige snarere enn den politiske delen av nasjonal miljøforvaltning. Delegasjonslederne er dermed godt rustet til å samhandle med det vitenskapelige miljøet, og resultatet har vist seg gjennom den anerkjente CAFF-kunnskapsproduksjonen omtalt ovenfor. De involverte forskerne blir ofte funnet giennom de nasjonale delegasjonslederne på en lignende måte som beskrevet for AMAP. Motsatt har likevel ikke delegasjonslederne i CAFF en kultur for å formulere politiske anbefalinger for oppfølging av kunnskap, og de har ifølge CAFF-informanter heller ikke noe utbredt ønske om å gjøre dette. Delegasjonsledere har mest operert i sin tradisjonelle rolle 
som kunnskapssammenstillere. I Norge har dette vært i forståelse med den politiske ledelsesmyndigheten, Klima- og miljødepartementet, som godkjenner mandatet for Norges opptreden i CAFF, og som Miljødirektoratet har jevnlig kontakt med i CAFF-saker. CAFF var i en ukjent rolle i å opptre "politisk» da arbeidsgruppen skulle formulere politiske anbefalinger til $A B A$. Ifølge informanter var de gjenstand for tekstforhandlinger i CAFF. Forhandlingene handlet imidlertid mer om spørsmålene som skulle dekkes av målene, enn om grad av presisjon i målene (CAFF, intervju 21.-22.11.19). Det var heller ikke omstridt at oppfølgingshandlingsplanen er rettet mot mer kunnskapsbyggende aktiviteter i Arktisk råd framfor oppfølgingsaksjoner på nasjonalt nivå.

Vi kan dermed konkludere med at CAFFs anbefalinger for det meste ikke henvender seg til nasjonale forvaltninger, og der det skjer, er de nokså generelle og har ikke knyttet overvåknings- og rapporteringsforpliktelser til seg. Anbefalingene retter seg mest mot ytterligere kunnskapsoppbygging. Det er flere grunner til at det er slik. Den ene er at kompleksiteten i feltet gjør det krevende å "oversette» kunnskap til nasjonale tiltak. Det er også slik at enkelte temaer er økonomisk og politisk kontroversielle, for eksempel verneområder. Igjen er det slik at kunnskap har best betingelser innenfor felt som er avgrenset og mindre kontroversielle, for eksempel ferskvannsøkosystemer og truede fuglearter. Endelig ser det ut til at CAFF generelt ikke oppfatter sin rolle som leverandør av policy anbefalinger til de arktiske landene, og at det er en stilltiende aksept av dette blant de enkelte regjeringene, SAO og Arktisk råd.

\section{PAME - en introduksjon}

Siden 1993 har PAME formelt fungert som en arbeidsgruppe hvis mandat er å fremme bærekraftig bruk av arktiske havområder og beskytte det marine miljøet fra land- og havbaserte forurensningskilder. Blant disse kan nevnes turisme, olje- og gassutvikling, kommersielt fiske og skipsfart. PAMEs aktiviteter utføres i henhold til toårige arbeidsplaner. Siden 2004 har i tillegg PAMEs marine strategiplaner sørget for en mer langsiktig og helhetlig ramme, ved å sette strategiske mål over tiårsperioder som gjelder hele rådet. Nåværende strategiplan er satt for perioden 2015-2025, med mål om å bedre kunnskapen om det marine miljøet i Arktis, overvåke marine økosystemer, beskytte marin biodiversitet og styrke økonomisk, sosial og kulturell velferd for lokalbefolkningen. PAMEs sekretariat er lokalisert på Island. Underlagt PAME er (per dags dato) ekspertgruppene Shipping Expert Group, Marine Protected Areas Expert Group, Shipping Expert Group, Resource Exploration and Development Expert Group, Marin Litter, Invasive Species og Ecosystem Approach Expert Group. I 2011 ble sistnevnte utvidet med representanter fra AMAP, CAFF og SDWG, noe som reflekterer økt samarbeid på tvers av arbeidsgrupper.

Blant Arktisk råds arbeidsgrupper er PAME den mest policyrettede. En særlig viktig oppgave for PAME er å utarbeide forslag til konkrete forebyggende tiltak (PAME, 2001). Dette kommer til uttrykk gjennom arbeidsgruppens policyanbefalinger, 
retningslinjer og handlingsprogram, som er rettet mot både Arktisk råd og de åtte medlemslandene. Disse produktene er ment å komplementere eksisterende rettslige reguleringer (Chater, 2014), og felles posisjoner og policyer spilles gjerne inn til Den internasjonale sjøfartsorganisasjonen (IMO), som i motsetning til Arktisk råds «myke» anbefalinger utarbeider juridisk bindende regelverk og standarder.

I henhold til PAMEs mandat har arbeidet med landbaserte forurensningskilder stått sentralt i flere av arbeidsgruppens første prosjekter. I tillegg til utviklingen av et regionalt handlingsprogram for landbaserte aktiviteter (dog med Russland i hovedfokus), ferdigstilt i 1998 og oppdatert i 2009 (PAME, 1998, 2009b; VanderZwaag, 2000), gjennomførte PAME en undersøkelse av det marine miljøet i Arktis, dets påvirkning av landbaserte aktiviteter samt eksisterende internasjonale instrumenter rettet mot denne typen forurensningskilder. Rapporten, som ble publisert i 1996, pekte på fire bekymringsverdige stoffer: POP-er, tungmetaller, radionuklider og olje (PAME, 1996). En statusrapport inkludert tiltak gjort for å følge opp rapportens anbefalinger, ble gitt ut i 2002 (PAME, 2002).

Det siste tiåret er det likevel på «havsiden» PAME først og fremst har markert seg, med temaer som skipsfart, tilnærming til økosystembasert forvaltning og marine verneområder på agendaen. En rekke prosjekter er gjennomført på disse feltene. Et av de største og viktigste arbeidene er Arctic Marine Shipping Assessment (AMSA) (PAME, 2009a) - PAMEs flaggskip og den første rapporten noensinne til å kartlegge skipsfart i nord og dens påvirkning på innbyggere i regionen og det marine miljøet. Rapporten tar også opp kravene økt skipsfart stiller til infrastrukturen i Arktis. Andre viktige eksempler er rapportene fra prosjektet Arctic Ocean Review phase I and II (2011 og 2013) (PAME, 2015a), som har bidratt til å sammenstille informasjon om miljøstatus, standarder og reguleringer i Arktis, med overordnet mål om å styrke styringen av det marine miljøet giennom samarbeidende, koordinerende og integrerte tilnærminger til forvaltning. Også Framework for a Pan-Arctic Network of Marine Protected Areas (PAME, 2015b) vurderes som et betydelig bidrag fra PAME når det gjelder framtidig samarbeid, forvaltning og tiltak for å verne sårbare marine områder i Arktis. Rapportens visjon er å etablere et pan arktisk nettverk av marine verneområder som går på tvers av landegrenser, men som kan forvaltes innenfor de arktiske statenes nasjonale lovverk. Hva gjelder marine verneområder, har PAME i stor grad overtatt hovedvekten av dette arbeidet fra CAFF, som tidligere var den viktigste arenaen innad i Arktisk råd for dette.

\section{PAME og bruk av kunnskap}

PAME er en viktig arena for samarbeid mellom arktiske stater og for utveksling av kunnskap og erfaring. Som den mest policy rettede arbeidsgruppen i Arktisk råd jobbes det først og fremst med å danne et solid kunnskapsgrunnlag innenfor de ulike prosjektene og problemstillingene som tas opp. Basert på slike sammenstillinger defineres nye kunnskapshull og policyanbefalinger. Generelt er det enklere å komme fram til samt legitimere policyanbefalinger jo mer forskningsbasert de er 
(PAME, intervju 29.10.19). Vitenskapelig enighet har betydning både for hvorvidt kunnskap blir produsert, og for hvorvidt det blir brukt. Samtidig er det alltid statene som legger premissene. Om vitenskapelige konklusjoner, til tross for bred enighet rundt dem, er i konflikt med medlemslandenes interesser eller synspunkter, vil disse ofte være avgjørende for om et prosjekt i det hele tatt blir vedtatt, og dermed for hvilken kunnskap som kan bli produsert og senere anvendt.

Når det gjelder bruk av kunnskap, peker ofte litteraturen på at presisjon i anbefalinger og rapporter er en viktig forutsetning. Blant PAMEs produkter finnes stor variasjon på dette punktet. En trend i senere år er likevel at anbefalinger peker på nødvendige tiltak som bør gjennomføres, samt på hvem som er ansvarlig for oppfølging, det være seg Arktisk råd, en konkret arbeidsgruppe eller medlemslandene selv. Rapporten Arctic Marine Shipping Assessment (AMSA) fra 2009 er et godt eksempel på slikt økt presisjonsnivå. Dette tatt i betraktning framstår ikke presisjon som avgjørende i vurderingen av kunnskapsoverføring mellom PAME og norsk forvaltning. En forklaring er at kunnskapsoverføring ofte skjer i prosessene før forhandling og utstedelse av policyanbefalinger - i workshops og diskusjoner mellom fageksperter fra, eller utpekt av, de nasjonale forvaltningene. En annen viktig forklaring er at Norge har en mer utviklet politikk på flere av PAMEs felt. Under slike omstendigheter er det generelt sett mindre sannsynlig at norsk forvaltning følger opp anbefalinger, presise eller ei. Arctic offshore oil and gas guidelines, først publisert i 1997 og oppdatert i 2002 og 2009, er et eksempel som belyser dette. Petroleumsnæringen har vært den viktigste næringen for Norge i mange år, og naturligvis er norske standarder svært høye. Retningslinjene fra PAME - som gjerne kan beskrives som et «minste felles multiplum»-produkt - er dermed lite relevante.

Hvis vi så vurderer betydningen av politisk og økonomisk kontrovers for bruken av kunnskap, er bildet litt annerledes. Igjen er det først og fremst statene og deres delegasjoner - i all hovedsak representanter fra forvaltningsapparatet - som legger premissene gjennom forhandlinger. I den grad temaer og prosjekter som foreslås, er sensitive, blir de gjerne skrinlagt tidlig i prosessen eller omformulert på et senere tidspunkt. Fra norsk side ønsker man for eksempel ikke å diskutere forvaltning av fiskebestander, heller ikke i prosjekter om økosystembasert forvaltning. Dette er et tema som behandles $\mathrm{i}$ andre fora, og anbefalinger - om de i det hele tatt ble framforhandlet - ville sannsynlig ikke ha blitt fulgt opp fra norsk side (PAME, intervju 29.10.19). Et annet delvis konfliktfylt tema er marine verneområder. Her har imidlertid input fra diskusjoner og workshops på temaet vært nyttig. Forvaltningen får faglig «added value» gjennom sin deltakelse, og kunnskapen kan være hensiktsmessig å ha med i mer nasjonale prosesser (PAME, intervju 10.11.17).

Ikke overraskende får tematikken som tas opp i PAME, både politisk og offentlig oppmerksomhet nasjonalt. Norge er en maritim stormakt. Informasjon og vurderinger som gjøres i arbeidsgruppen, er viktig for å løfte standarder blant medlemslandene, men også i nasjonalt arbeid ellers. I stor grad regnes rapporter fra PAME som faglig solide, og kunnskap fra dem er anvendt av forvaltningen. Spesielt nyttig beskrives 
kunnskap og metodetilnærming innen økosystembasert havforvaltning (PAME, intervju 10.11.17). Nøyaktig hvilken kunnskap som brukes, avhenger til dels av behov, til dels av hvilke saker som står sentralt på agendaen. PAME-rapporter er for eksempel anvendt i utarbeidelsen av de norske forvaltningsplanene for Barentshavet. Dette kommer også til uttrykk i en rapport fra Faglig forum med flere, hvor det henvises til PAMEs rapporter som del av det faglige grunnlaget for oppdatering av Forvaltningsplanen for Barentshavet og havområdene utenfor Lofoten i 2010 (Faglig forum, Overvåkingsgruppen \& Risikogruppen til den interdepartementale styringsgruppen for forvaltningsplanen, 2010). Den siste tiden har flere av PAMEs prosjekter også gitt innspill til forvaltningens pågående arbeid med hav og prosessene rundt havstrategien og stortingsmeldingen om hav. Marin forsøpling er et annet viktig t tema, hvor Norge allerede er aktivt globalt og nasjonalt. Informasjon fra det pågående PAME-prosjektet Desktop study of marine litter and microplastics in the Arctic beskrives i så henseende som nyttig (PAME, 2017a), både for å utvide kunnskapsbasen i videre norsk arbeid og for å være i tet internasjonalt (PAME, intervju 02.11.17, 29.10.19). Her ser man igjen at arbeidet i Arktisk råd kan understøtte oppfatninger om arktiske fellesinteresser. At prosjektet er viktig, reflekteres blant annet i betydelige økonomiske bidrag og lederskap fra norsk side. Generelt pekes det også på at tilstedeværelse i PAME gir faglig input som ofte automatisk tas videre i det nasjonale arbeidet - selv om dette ikke nødvendigvis er enkelt å spore direkte.

Likevel, som det allerede vises tendenser til ovenfor, er det ikke alltid slik at kunnskap oppstår forut for og er klart adskilt fra det forvaltningsmessige og politiske nivået. Kunnskapsoverføring er ikke alltid en enkel lineær prosess. Når det gjelder PAME, er det en sterk kobling mellom arbeidsgruppen og norsk forvaltning $i$ hovedsak er det representanter fra departementer og direktorater som deltar i delegasjonen. Også norsk ekspertise har ofte rot i forvaltningssystemet, enten gjennom egne fageksperter eller ved at forvaltningen leier inn konsulenter for å utføre et arbeid eller prosjekt forvaltningen har ansvar for i PAME. Medlemslandenes delegasjoner er også de som definerer og forhandler fram prosjekter og anbefalinger, selv om eksperter kan gi input i disse prosessene. Dette organisatoriske utgangspunktet gir selvsagt anledning til å fremme norske egeninteresser og standarder innad i Arktisk råd, hvilket også skjer aktivt. En tydelig tendens i empirien er at kunnskapsoverføring skjer fra norsk forvaltning til PAME - kanskje mer enn omvendt.

Et interessant funn er norske bidrag for å få Arktisk råds medlemsland opp på et høyere nivå, både gjennom initiering og finansiering av prosjekter. Eksempelvis illustreres dette gjennom Norges aktive rolle i oppfølgingen av $A M S A$ rapporten og dens anbefalinger, herunder utviklingen av et overvåkningssystem for arktisk skipsfart ved bruk av Havbase, ${ }^{13}$ og utredningen av alternative drivstoff til

\footnotetext{
${ }^{13}$ Prosjektnavn: Arctic Ship Traffic Data (ASTD), svarer til $A M S A$-anbefaling IIIB.
} 
tungolje. ${ }^{14}$ Norge har også deltatt i PAMEs arbeid med økosystembasert forvaltning. Dette begrepet ble satt på den nasjonale agendaen gjennom St.meld. nr. 12 (20012002) Rent og rikt hav (Klima- og miljødepartementet, 2002). Etter at økosystembasert forvaltning også ble vedtatt som et overordnet prinsipp i PAMEs marine strategiplan (PAME, 2004), ble temaet løftet fram under det norske formannskapet (2006-2009), blant annet gjennom den norskinitierte rapporten Best Practices in Ecosystem-Based Oceans Management in the Arctic. Norge ledet også Ecosystem Approach Expert Group i perioden 2009-2011. Prosjekter knyttet til tungolje er Norge fortsatt en pådriver for. Opprinnelig forsøkte Norge å fremme et forbud mot bruk av tungolje i Arktis, som innført i området rundt Svalbard. Det har imidlertid ikke lyktes å få med øvrige medlemsland på dette. Tungoljeprosjektet ble derfor bestående av en utredning av alternative drivstoff og risikovurderinger, resulterende i flere tekniske rapporter. Per dags dato leder Norge et prosjekt hvor konsekvenser av et forbud mot tungolje som drivstoff vurderes (DNV GL, 2019). Et forbud som også inkluderer last og transport, har så langt ikke vært mulig å få gjennomslag for, selv om det fra norsk side anses å være interessant.

Arbeidet med tungolje er tydelig en sterk norsk prioritet, men er også interessant av andre grunner. Per nå utarbeides det i PAME en oppsummering som skal framlegges IMO. Til syvende og sist er det kanskje her den viktigste kunnskapsoverføringen finner sted. Også PAMEs arbeid med Polarkoden og senere regional avfallshåndtering for skipsfart understreker arbeidsgruppen som en viktig arena for å danne felles posisjoner (PAME, 2017b). I 2019 har IMO for første gang deltatt på et PAME-møte, og linken mellom de to ser ut til å styrkes. På sikt kan dette samarbeidet mellom medlemslandene i PAME og mellom PAME og IMO bidra til å styrke internasjonalt regelverk $\mathrm{i} ø$ ønsket retning for Norge.

Oppsummert er det ingen tvil om at kunnskapen produsert i PAME, blir brukt. I denne arbeidsgruppen er det likevel slik at faktorene vitenskapelig enighet og politisk og økonomisk kontrovers ikke er så avgiørende. Dette skyldes at medlemslandene gjennom forhandlinger om prosjekter og anbefalinger prioriterer egne interesser, og at man går bort fra temaer som er sensitive og vanskelige å få gjennomslag for $\mathrm{i}$ et konsensusbasert organ. Presisjon er heller ikke av stor betydning når vi ser på Norge, nettopp fordi Norge allerede har høye standarder. At tematikken i PAME derimot får mye oppmerksomhet i det norske forvaltningsapparatet - selvsagt fordi Norge er en maritim stormakt - ser ut til å være betydningsfullt. Også hvordan forholdet mellom PAME og forvaltningen er organisert - hvor nært koblet de er - har effekt. Både i den forstand at forvaltningen selv bruker kunnskapen nasjonalt, men også i et samproduksjonsperspektiv er det tydelig at forvaltningen bruker kunnskapsprosesser i Arktisk råd til å fremme sin egen agenda og til å skape felles posisjoner inn mot internasjonale regulerende myndigheter.

${ }^{14}$ Prosjektnavn: Heavy Fuel in the Arctic, svarer til $A M S A$-anbefaling IB. 


\section{Oppsummering - kunnskap i alle retninger}

De tre arbeidsgruppene viser at spennet i Arktisk råd er stort. AMAPs brede tilstandsvurderinger av regional forurensning, CAFFs kunnskapsoppbygging om arktiske økosystemer og PAMEs mer policyrettede fokus på for eksempel shipping har alle bidratt til å øke vår forståelse av miljømessige og klimatiske utfordringer i regionen. Alle arbeidsgruppene har likevel det kjennetegnet at suksessen har vært størst på den regionale (kunnskapsoppbygging i Arktisk råd) og internasjonale scene (innspill til internasjonale klima- og miljøforhandlinger). Norge, som har vært vår illustrerende case, har i stor grad vært i forkant når det gjelder nasjonale reguleringer, og har heller, stort sett, brukt kunnskapen fra arbeidsgruppene inn i internasionale forhandlinger og kunnskapsoppbygging nasjonalt. For AMAPs del er arbeidet opp mot Stockholm-konvensjonen, Minimata-konvensjonen og de internasjonale klimaforhandlingene gode eksempler. Når det gjelder CAFF, er den nære koblingen opp mot globalt arbeid med biologisk mangfold tydelig gjennom for eksempel CBDog CMS-konvensjonene. PAME har på sin side spilt inn i IMO, blant annet i forbindelse med Polarkoden. Her har Norge brukt PAME som kunnskapsaktør for å argumentere for strengere regionale reguleringer. En viktig erkjennelse er uansett at utfordringer i Arktis i stor grad er importert. Dermed har de arktiske statene fellesinteresser i å fronte fellesutfordringer globalt. Det er selvfølgelig store variasjoner her, men det er like fullt en bærebjelke i samarbeidet. Samarbeidet bidrar samtidig ikke bare til å dokumentere eksisterende fellesinteresser, men også til å skape dem. Vi må heller ikke glemme hva slags type forum Arktisk råd er. Rådet er kun politisk bindende, noe som igjen kan gjøre det lettere å finne en felles plattform hvor statene i enkelte tilfeller har muligheten til å formulere nokså presise og tydelige anbefalinger - de trengs jo strengt tatt ikke å følges. Det er likevel ulik grad av normativt press, og her ser vi også at arbeidsgruppene har ulike kulturer, både fra prosjekt til prosjekt og mellom seg.

Vanskeligere er det å spore den direkte effekten av arbeidet i Arktisk råds arbeidsgrupper på nasjonalt nivå og i norsk miljøforvaltning, som vi spesifikt har sett på. Dette skyldes først og fremst at arbeidsgruppene ofte er tilbakeholdne med å opptre normativt og formulere noe som kan oppfattes som politisk. Det gjelder ikke minst når det handler om mulig begrensning av suverene rettigheter, som anbefalinger om maritime verneområder og tiltak for hvordan man bør regulere nasjonale utslipp av klimagasser. Det finnes likevel unntak, for eksempel de mer spisse anbefalingene fra CAFFs handlingsplaner for truede sjøfuglarter og AMAPs arbeid med miljøgifter. En ytterligere grunn til at effekten er vanskelig å måle i norsk forvaltning, er at Norge ofte er i forkant når det gjelder tiltak foreslått av arbeidsgruppene, og at ambisjonen heller har vært å «bruke» arbeidsgruppene for at de øvrige landene i Arktisk råd kan komme på samme nivå. PAMEs arbeid med shipping er et godt eksempel her.

Konklusjonen er at vitenskapelig kunnskap produsert i Arktisk råds arbeidsgrupper, går i en rekke ulike retninger, fra direkte inn i internasjonale forhandlinger, 
eventuelt via norsk forvaltning inn i internasjonale forhandlinger, som eksemplet med POP-er viser, eller som på tilpasningsfeltet, som beslutningsgrunnlag for lokale tiltak. Effekten på nasjonalt nivå er ofte av mer indirekte natur, gjennom for eksempel å heve kunnskapsbasen i miljøforvaltningen. Hvis vi ser på de fire analytiske faktorene som ble introdusert i innledningen, og som har fulgt oss gjennom presentasjonen av de tre arbeidsgruppene, ser vi enkelte tendenser. Ikke overraskende er vitenskapelig enighet om mål og middel ofte en nødvendighet for å lykkes. Vi ser også at det innenfor avgrensede felt naturlig nok er enklere å komme med presise anbefalinger. Disse vil da lettere fanges opp av forvaltning, delvis uavhengig av hvordan forholdet mellom kunnskapsprodusentene og forvaltningen er organisert. Dette er igjen koblet til graden av offentlig og politisk oppmerksomhet om det gitte temaet. Bruken av kunnskap er også nært koblet til hvor politisk og økonomisk kontroversielt et gitt tiltak er. Hva er de økonomiske konsekvensene av å følge vitenskapelige anbefalinger? Det alle casene våre viser, er likevel at vi må gå ut over den lineære modellen for å forstå hvordan og hvorfor kunnskap blir brukt. I enhver analyse må vi stille oss spørsmål som: Hvem formulerer de vitenskapelige problemstillingene? Hvordan og hvem kondenserer de empiriske funnene til politiske anbefalinger? Arbeidsgruppene, og da særlig delegasjonslederne (som primært er fra miljøforvaltningen i de arktiske statene), vil være sensitive for politiske føringer når anbefalinger formuleres. Det er ikke slik at vitenskap oppstår frakoblet fra forvaltning og politikk. Den samproduseres i spennet mellom disse tre nivåene. I artikkelen har vi vist kompleksiteten i forholdet mellom vitenskap, forvaltning og politikk. Vi har argumentert for en bred analytisk inngang for ikke å miste dette mangfoldet av syne. Målet med denne oversiktsartikkelen er å legge til rette for flere dyptgående caseanalyser, hvor oppmerksomheten er rettet mot hvordan kunnskap om Arktis blir utviklet og brukt. Dette er igjen et argument for flere tverrvitenskapelige analyser, hvor den naturvitenskapelige kunnskapssammenstillingen, i dette tilfellet fra Arktisk råd, suppleres med analyser av hvordan og hvorfor noen typer kunnskap vinner fram og i siste instans blir anvendt.

\section{Forkortelser}

AACA - Adaptation Actions for a Changing Arctic

ABA - Arctic Biodiversity Assessment

ABDS - Arctic Biodiversity Data Service

ACIA - Arctic Climate Impact Assessment

AMAP - Arctic Monitoring and Assessment Program

AMBI - Arctic Migratory Birds Initiative

AMSA - Arctic Marine Shipping Assessment

ARIAS - Arctic Invasive Alien Species Strategy and Action Plan

ASTI - Arctic Species Trend Index

CAFF - Conservation of Arctic Flora and Fauna 
CBD - Convention on Biological Diversity

CBMP - Circumpolar Biodiversity Monitoring Program

CMS - Convention on the Conservation of Migratory Species of Wild Animals

IASC - International Arctic Science Committee

IPCC - Intergovernmental Panel on Climate Change

PAME - Protection of Arctic Marine Environment

POP-er - Persistent Organic Pollutants

SAO - Senior Arctic Official

SDWG - Sustainable Development Working Group

SWIPA - Snow, Water, Ice and Permafrost in the Arctic

UNEP - UN Environment Programme

\section{Om forfatteren}

Svein Vigeland Rottem er seniorforsker ved Fridtjof Nansen Institutt. Rottems forskning er særlig rettet mot sikkerhetspolitikk i Arktis, arktiske styringsmekanismer, forholdet mellom politikk og vitenskap og Arktisk råd. Han har publisert en rekke bøker, akademiske artikler og reporter om disse temaene.

Ida Folkestad Soltvedt er utdannet statsviter ved Universitetet i Oslo. Hun har tidligere jobbet som forsker ved Fridtjof Nansens Institutt, med særlig fokus på Arktisk råd, kunnskapsoverføring og nasjonal implementering av Arktisk råds' myke policy-anbefalinger.

Christian Prip er seniorpolitisk analytiker ved Fridtjof Nansens Institutt. Hans kjerneområde for forskning er internasjonal miljøstyring med spesiell vekt på biologisk mangfold, hav og Arktis. Før han ble forsker, har Prip 20 års erfaring som hovedforhandler i internasjonale miljøforhandlinger for hjemlandet Danmark.

\section{Referanser}

AMAP. (1998). AMAP assessment report: Arctic pollution issues. Arctic Monitoring and Assessment Programme (AMAP), Oslo, Norge (s. xii-859). Hentet 26. mai 2020 fra https://www.amap.no/documents/doc/amapassessment-report-arctic-pollution-issues $/ 68$

AMAP. (2011). Snow, water, ice, permafrost in the Arctic (SWIPA): Climate change and the ceyosphere. Arctic Monitoring and Assessment Programme (AMAP), Oslo, Norge (s. xii-538). Hentet 26. mai 2020 fra https://www.amap.no/documents/doc/snow-water-ice-and-permafrost-in-the-arctic-swipa-climatechange-and-the-cryosphere/743

AMAP. (2015a). AMAP assessment 2015: Black carbon and ozone as Arctic climate forcers. Arctic Monitoring and Assessment Programme (AMAP), Oslo, Norge (s. vii-116). Hentet 26. mai 2020 fra https://www.amap. no/documents/doc/amap-assessment-2015-black-carbon-and-ozone-as-arctic-climate-forcers/1299

AMAP. (2015b). AMAP expert/assessment groups: The role of experts, procedures for nominating and supporting experts, appointing reviewers and conducting peer reviews. Arctic Monitoring and Assessment Programme (AMAP), Oslo, Norge (s. 1-7). Hentet 21. mai 2020 fra https:/www.amap.no/documents/download/2294/inline

AMAP. (2015c). Arctic pollution issues 2015. Summary for policy-maker. Arctic Monitoring and Assessment Programme (AMAP), Oslo, Norge (s. 1-12). Hentet 26. mai 2020 fra https:/www.amap.no/documents/ doc/summary-for-policy-makers-arctic-pollution-issues-2015/1195 


\section{Svein Vigeland Rottem, Ida Folkestad Soltvedt og Christian Prip}

AMAP. (2017a). Adaptation actions for a changing Arctic: Perspectives from the Barents Area. Arctic Monitoring and Assessment Programme (AMAP), Oslo, Norge (s. xiv-267). Hentet 26. mai 2020 fra https://www.amap. no/documents/doc/adaptation-actions-for-a-changing-arctic-perspectives-from-the-barents-area/1604

AMAP. (2017b). SWIPA. Summary for policy-makers. Arctic Monitoring and Assessment Programme (AMAP), Oslo, Norge (s. 1-20). Hentet 26. mai 2020 fra https://www.amap.no/documents/doc/snow-water-iceand-permafrost.-summary-for-policy-makers/1532

AMAP. (2019). AMAP climate change update 2019: An update to key findings of snow, water, ice and permafrost in the Arctic (SWIPA) 2017. Arctic Monitoring and Assessment Programme (AMAP), Oslo, Norge (s. 1-12). Hentet 26. mai 2020 fra https://www.amap.no/documents/doc/amap-climate-change-update-2019/1761

AMAP, CAFF \& IASC. (2005). Arctic climate impact assessment (s. 1-1020). Cambridge University Press, Cambridge. Hentet 26. mai 2020 fra https:/www.amap.no/documents/doc/arctic-arctic-climate-impactassessment/796

Andresen, S., Rosendal K. \& Skjærseth, J. B. (2017). Designing knowledge-based, integrated management systems for environmental governance. I A. Dinar (Red.), Natural resources and environmental policy in the era of global change (s. 439-456). Singapore: World Scientific.

Andresen, S., Skodvin, S. T., Underdal A. \&Wettestad, J. (2000). Science and politics in international environmental regimes. Manchester, England: Manchester University Press.

Arktisk råd. (2013). Arctic Council rules of procedure. Hentet 26. mai 2020 fra https://oaarchive.arcticcouncil.org/handle/11374/940

Beck, S. (2010). Moving beyond the linear model of expertise? IPCC and the test of adaptation. Regional Environmental Change, 11(2), 297-306.

Berntsen, B. (2011). Grønne Linjer. Natur- og miljøvernets historie i Norge. Oslo: Unipub.

CAFF. (1993). Program for the conservation of Arctic flora and fauna framework document. Hentet fra http://www. caff.is/administrative-series/all-administrative-documents/137-caff-framework-document

CAFF. (1996). CPAN strategy and action plan, CAFF habitat conservation report no. 6. Directorate for Nature Management (DN), Trondheim, Norge (s. 1-24). Hentet 26. mai 2020 fra https://www.caff.is/strategiesseries/95-cpan-strategy-and-action-plan

CAFF. (u.å.). Arctic species trend index. Hentet 26. mai 2020 fra https://www.caff.is/asti/about

CAFF. (2013). Arctic biodiversity assessment. Status and trends in Arctic biodiversity. Conservation of Arctic Flora and Fauna (CAFF), Akureyri, Island (s. 1-674). Hentet 26. mai 2020 fra https://www. arcticbiodiversity.is/

CAFF. (2015a). Actions for Arctic biodiversity 2013-2021. Implementing the recommendations of the Arctic biodiversity assessment. Conservation of Arctic Flora and Fauna (CAFF), Akureyri, Island (s. 1-30). Hentet 26. mai 2020 fra https:/www.caff.is/administrative-series/293-actions-for-arctic-biodiversity-2013-2021implementing-the-recommendations-of-th

CAFF. (2015b). Arctic migratory birds initiative (AMBI) work plan 2015-2019. Conservation of Arctic Flora and Fauna, Akureyri (CAFF), Island (s. 1-26). Hentet 26. mai 2020 fra https://www.caff.is/strategiesseries/295-arctic-migratory-birds-initiative-ambi-work-plan-2015-2019

CAFF. (2017a). State of the Arctic marine biodiversity report. Conservation of Arctic Flora and Fauna, Akureyri (CAFF), Island (s. 1-197). Hentet 26. mai 2020 fra https://www.arcticbiodiversity.is/marine

CAFF. (2017b). Arctic invasive alien species. Conservation of Arctic Flora and Fauna (CAFF), Akureyri, Island (s. 1-19). Hentet 26. mai 2020 fra https://www.caff.is/invasive-species

CAFF. (2019a). State of the Arctic freshwater biodiversity: Key findings and advice for monitoring. Conservation of Arctic Flora and Fauna (CAFF), Akureyri, Island (s. 1-15). Hentet 26. mai 2020 fra https://www.caff. is/freshwater/freshwater-monitoring-publications/469-state-of-the-arctic-freshwater-biodiversity-keyfindings-and-advice-for-monitori

CAFF. (2019b). Mainstreaming biodiversity in Arctic mining: Challenges and proposed solutions. Conservation of Arctic Flora and Fauna (CAFF), Akureyri, Island (s. 1-29) Hentet 26. mai 2020 fra https://www.caff. is/strategies-series/468-mainstreaming-biodiversity-in-arctic-mining-challenges-and-proposed-solutions

CAFF \& CBMP. (2018). The circumpolar biodiversity monitoring programme (CBMP). Hentet 26. mai 2020 fra https://www.caff.is/monitoring

Chater, A. (2014). Arctic Council. I J. Sperling (Red.), Handbook of governance and security (s. 489-503). London England: Edward Elgar.

Clark, R., Meidinger, E. E., Rayner, J., Miller, G., Layseca,M., Monreal, S. ... Shannon, M. A. (1998). Integrating science and policy in natural resource management: Lessons and opportunities from North America (Rapport, USDA Forest Service). Hentet 26. mai 2020 fra http://www.fs.fed.us/pnw/pubs/gtr_441.pdf 
DNV GL. (2019). Alternative fuels in the Arctic (Rapport nr. 2019-0226) Hentet 26. mai 2020 fra https://www. pame.is/index.php/document-library/shipping-documents/heavy-fuel-oil-documents/452-report-on-theenvironmental-economic-technical-and-practical-aspects-of-the-use-by-ships-in-the-arctic-of-alternativefuels-1/file

Duyck, S. (2012). Which canary in the coalmine? The Arctic in the international climate change regime. IT. Koivurova, G. Alfredsson \& W. Hasanat (Red.), The yearbook of polar law (4. utg., s. 583-617). Leiden: Brill Publishers.

Faglig forum, Overvåkingsgruppen \& Risikogruppen til den interdepartementale styringsgruppen for forvaltningsplanen. (2010). Det faglige grunnlaget for oppdateringen av forvaltningsplanen for Barentshavet og havområdene utenfor Lofoten (Rapport). Hentet 26. mai 2020 fra https://www.regjeringen.no/globalassets/ upload/md/vedlegg/hav_vannforvaltning/forvaltningsplanen_barentshavet/rapporter/faglig_forum_ rapport_lofoten-barentshavet_150410.pdf

FN. (u.å.). Millenium ecosystem assessment. Hentet 27. november 2018 fra https://www.millenniumassessment.org/ en/index.html

Jasanoff, S. (2004). States of knowledge:The co-production of science and the social order. London, England: Routledge.

Kankaanpää, P. \& Young, O. (2012). The effectiveness of the Arctic Council. Polar Research, 31(1).

Klima- og miljødepartementet. (2002). Rent og rikt hav (St.meld. nr. 12 (2001-2002)). Hentet fra https://www. regjeringen.no

Klima- og miljødepartementet. (2015). Natur for livet - Norsk handlingsplan for naturmangfold (Meld. St. 14 (2015-2016)). Hentet 26. mai 2020 fra www.regjeringen.no/contentassets/902deab2906342dd 823906d06ed05db2/no/pdfs/stm201520160014000dddpdfs.pdf

Klima- og miljødepartementet. (2016). Tildelingsbrev 2016 for Miliødirektoratet. Hentet 26. mai 2020 fra https://www.regjeringen.no/contentassets/ab73dcc339ba4a498f8e 17 df76305bed/miljodirektoratet_ tildelingsbrev_2016.pdf

Klima- og miljødepartementet. (2018). Tildelingsbrev 2018 for Miljødirektoratet. Hentet 26. mai 2020 fra https://www.regjeringen.no/contentassets/d3b5f27dd4d34f2085b505b6df7fb5d4/miljodirektoratet_ tildelingsbrev_2018.pdf

Lidskog, R. \& Sundqvist, G. (2015). When does science matter? International relations meets science and technology studies. Global Environmental Politics, 15(1), 1-20.

PAME. (1996). Report to the third minesterial conference on the protection of the Arctic environment. Protection of the Arctic Marine Environment (PAME), Akureyri, Island (s. 1-156). Hentet 26. mai 2020 fra https:// www.pame.is/images/01_PAME/Framework_Documents/PAME-1996-Report.pdf

PAME. (1998). Regional programme of action for the protection of the Arctic marine environment from land-based activities. Protection of the Arctic Marine Environment (PAME), Akureyri, Island (s. 1-17). Hentet 26. mai 2020 fra https:/www.pame.is/images/02_Document_Library/RPA_Reports/RPA_1998/RPA_English.pdf

PAME. (2001). PAME's contribution to the Arctic Council. Hentet 26. mai 2020 fra https://oaarchive.arcticcouncil.org/bitstream/handle/11374/472/ACSAO-FI02_5_3_3_pame_wssd.pdf?sequence=1\&isAllowed=y

PAME. (2002). PAME report on the status of 1996 recommendations. Protection of the Arctic Marine Environment (PAME), Akureyri, Island (s. 1-6). Hentet 26. mai 2020 fra https://oaarchive.arctic-council.org/bitstream/ handle/11374/1591/MM03_PAME_Attachment_2.pdf?sequence=3\&isAllowed=y

PAME. (2004). Arctic Marine Strategic Plan. Akureyri, Iceland: PAME. Hentet fra https://www.pame.is/ document-library/amsp-documents

PAME. (2009a). Arctic marine shipping assessment (AMSA). Protection of the Arctic Marine Environment (PAME), Akureyri, Island (s. 1-194). Hentet 26. mai 2020 fra https://pame.is/index.php/projects/arctic-marine-shipping/ amsa

PAME. (2009b). Regional programme of action for the protection of the Arctic marine environment from land-based activities. Hentet 26. mai 2020 fra https:/www.pame.is/images/02_Document_Library/RPA_Reports/ RPA_2009/PAME_RPA_layout_031109-_leirtt_nv_09.pdf

PAME. (2015a). Arctic ocean review phase I and II (2011, 2013). Protection of the Arctic Marine Environment (PAME), Akureyri, Island (s. 20-21). Hentet 26. mai 2020 fra https://arctic-council.org/index.php/en/ our-work2/8-news-and-events/327-arctic-ocean-review-project-aor

PAME. (2015b). Framework for a pan-Arctic network of marine protected areas. Protection of the Arctic Marine Environment (PAME), Akureyri, Island (s. 1-49). Hentet 26. mai 2020 fra https://oaarchive.arctic-council. org/handle/11374/417

PAME. (2017a). PAME work plan 2017-2019. Protection of the Arctic Marine Environment (PAME), Akureyri, Island (s. 1-43). Hentet 26. mai 2020 fra https:/oaarchive.arctic-council.org/bitstream/handle/ 11374/1935/PAME_Work_Plan_2017-2019.pdf?sequence=1\&isAllowed=y 
PAME. (2017b). Regional waste management strategies for Arctic shipping; Regional reception facilities plan. Protection of the Arctic Marine Environment (PAME), Akureyri, Island (s. 1-22). Hentet 26. mai 2020 fra https://oaarchive.arctic-council.org/handle/11374/1932

Platjouw, F. M., Steindal, E. H. \& Borch, T. (2018). From Arctic science to international law: The road towards the Minamata Convention and the role of the Arctic Council. Arctic Review on Law and Politics, 9, $226-243$.

Prip, C. (2016). The Arctic Council and biodiversity - need for stronger management framework? Nordisk Miljörättslig Tidskrift, 2, 37-53.

Regjeringen. (2017). Nordområdestrategi - mellom geopolitikk og samfunnsutvikling. Hentet 26. mai 2020 fra https://www.regjeringen.no/no/dokumenter/strategi_nord/id2550081/

Rottem, S. (2017). The use of Arctic science: POPs, Norway and the Stockholm Convention. Arctic Review on Law and Politics, 8, 246-269.

Rottem, S. (2019). The Arctic Council - between environmental protection and geopolitics. Singapore: Palgrave Pivot.

Soltvedt, I. \& Rottem, S. (2016). The Arctic Council: Policy recommendations and national implementation (FNI Rapport 7/2016). Lysaker: Fridtjof Nansens Institutt.

Soltvedt, I. (2017). Soft law, solid implementation? The influence of precision, monitoring and stakeholder involvement on Norwegian implementation of Arctic Council recommendations. Arctic Review on Law and Politics, 8, 73-94.

Sundqvist, G. \& Hermansen E. A. (2015). Formalization and separation: A systematic basis for interpreting approaches to summarizing science for climate policy. Social Studies of Science, 45(3), 416-440.

Utenriksdepartementet. (2011). Nordområdene. Visjon og virkemidler (nordområdemeldingen) (Meld. St. 7 (20112012)).. Hentet 26. mai 2020 fra https://www.regjeringen.no/no/dokumenter/nordomradene-visjon-ogvirkemidler---en-/id664906/

Utenriksdepartementet. (2014). Nordkloden (Statusrapport 2014). Hentet 26. mai 2020 fra https://www. regjeringen.no/no/dokumenter/nordkloden/id2076193/

VanderZwaag, D. (2000). Land-based marine pollution and the Arctic. I D. Vidas, Protecting the polar marine environment: Law and policy for pollution prevention. Cambridge, England: Cambridge University Press.

\section{Abstract in English \\ The Arctic Council Between Science, Managment and Policy}

What has often been lacking in the scholarly literature on environmental and climatic changes in the Arctic are analyses addressing what determines the influence of scientific knowledge on regulations of relevance to the Arctic. The purpose of this article is to analyse the relationship between the production and systematisation of knowledge (including policy recommendations arising from this work) on Arctic issues and the Norwegian management system (overseen by, among other bodies, the Norwegian Environment Agency and Ministry of Climate and Environment). The article focuses on three of the Arctic Council's working groups: 1) Arctic Monitoring and Assessment Programme (AMAP); 2) Conservation of Arctic Flora and Fauna (CAFF); and 3) Protection of Arctic Marine Environment (PAME). The focus is on state of knowledge, degree of political and economic controversy in the issue area, the importance of the matter in public opinion and among policy makers, and management design.

Keywords: Arctic Council • AMAP · CAFF • PAME • knowledge • national environmental management 